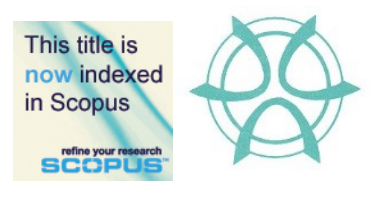

PLANNING MALAYSIA:

Journal of the Malaysian Institute of Planners

VOLUME 18 ISSUE 2 (2020), Page 1 - 11

\title{
ASSESSMENT OF THE HISTORIC INTERIOR OF CARCOSA HERITAGE BUILDING, KUALA LUMPUR FOR BUILDING CONSERVATION
}

\author{
Siti Norlizaiha Harun ${ }^{1}$, Norashikin Abdul Karim ${ }^{2}$, \\ Afzanizam Muhammad ${ }^{3} \&$ Shaari Mohd Sood ${ }^{4}$ \\ ${ }^{123}$ Faculty of Architecture, Planning \& Surveying \\ UNIVERSITI TEKNOLOGI MARA \\ ${ }^{4}$ Cluster of Heritage \& Civilization \\ ISLAMIC UNIVERSITY OF MALAYSIA
}

\begin{abstract}
An assessment of historic buildings, its history and conditions are essential in the study of buildings conservation. Other than architecture history and building defects, the interior scheme of building, the decorations, the building's form and space interior layout are also some significant aspects that need to be analysed in building conservation study. In current practice, the change of use of any heritage building will need approval from the National Heritage Department (NHD). The report of history and building condition is the one of the main documents needed to be submitted for the approval process. The main objective of this research is to analyse the buildings based on the original materials, form, function, decoration, and layout. The methods used for this research include in-depth building investigation, analysis, and interpretation; backed up by measured drawing and historical assessment. The analysis involved the mapping of original and existing spaces and then analysed the unique characters of the interior using a series of photos categorised based on time or dates of the photos. From this analysis, the authenticity of the space can be identified and recommendations on better usage of spaces of these historic buildings can be proposed to the National Heritage Department.
\end{abstract}

Keywords: Assessment, Interior, Authenticity, Conservation, Restoration 
Siti Norlizaiha Harun, Norashikin Abdul Karim, Afzanizam Muhammad \& Shaari Mohd Sood

Assessment of the Historic Interior of Carcosa Heritage Building, Kuala Lumpur for Building Conservation

\section{INTRODUCTION}

In Malaysia, the conservation procedure of historic buildings follows the guidelines provided by the National Heritage Department Malaysia (NHDM). The Historic Building Conservation Guideline (National Heritage Department Malaysia [NHDM], 2017) has outlined the process and suitable methods to investigate historic buildings which are divided into three sections, namely architectural research, documentation on measured drawings, and dilapidation survey with laboratory analysis. Before starting any exploration of a historic site, the purpose of investigation needs to be determined. McDonalds (1994) in National Park Services (NPS) Preservation Brief stated that both the purpose and scope of investigation need to be determined before formulating a particular approach. For example, investigation strictly for research purposes could produce information for an architectural survey or a historic designation application at the local, state or national level. The United Nations Educational, Scientific and Cultural Organization (UNESCO) has established guidance and standard to evaluate the authenticity and integrity of a heritage building (Nara Document on Authenticity, 1994). The authenticity and historic integrity in the context of the heritage building is linked to the uniqueness of the building characteristics and the value of the historic places (Brida, Disegna \& Scuderi, 2012). In other scenarios, most buildings were built with a specific reason and purpose, and the history of the buildings started when the building started to be constructed. Because of that, the object of conservation, especially a historic building, must be thoroughly researched, and it must be regarded as an object created in space and history (Weaver, 1997). Moreover, the condition, integrity and authenticity of the story line or the history of the building need to be validated (Pearson \& Marshall, 2011). In this research, since Carcosa has been vacated for a while, building investigations were conducted to determine the magnitude of the damages and renovation works that have been made. The results of the study were intended to be used to present suitable proposals for future use of similar historic buildings to the relevant authorities.

\section{HISTORICAL BACKGROUND OF CARCOSA}

The Carcosa building is located near Perdana Lake Garden, Kuala Lumpur. Its construction began in 1896 by the first British Resident in Malaya, Sir Frank Swettenham. Designed by Arthur Benison Hubback and the construction was under the supervision of the State Engineer of Selangor Public Work Department, Charles Edwin Spooner, the ground floor area was built to accommodate major social gatherings and an upper floor was designed with private sitting room, 
study, and seven bedrooms, each room located along a long veranda. The outbuildings included stables and several tennis courts. The estimated cost of the palatial building, built in the eclectic fusion of Neo-Gothic and Tudor Revival styles, was about 25,000 pounds (Seng, 2018). Carcosa began life as home to the Resident-General in 1898. After Swettenham, Carcosa was occupied by British high officials and as a temporary residence for the Governor of the Straits Settlements, who resided in Singapore. Throughout the Second World War, the Japanese army used the building as the head station for their officials. By 1946, Carcosa served its original function as British high-officer official residence. On January 21,1948 , the building was used as the venue to sign the document of the Federation of Malaya between the Malay Rulers and the British Empire. On September 12, 1956, the Chief Minister of Malaya, who later became Prime Minister of Malaysia, Tunku Abdul Rahman, handed Carcosa to the British government as a gift and the building has been used as the British High Commissioner building. On 5th August 1957, the building was used again as the venue to sign the document of the Independence Malaysia. In early 1987, the Malaysia government decided to convert the building into a hotel. The colonial architecture and interior designs complemented the colonial-themed hotel service perfectly. In its inaugural year as a hotel, Carcosa Seri Negara served as the temporary official residence for Queen Elizabeth II and Prince Philip during the 1989 Kuala Lumpur Commonwealth Heads of Government Meeting. The Carcosa building has been gazetted as a National Heritage Building, under the National Heritage Act 2005 (Act 645) on July 6, 2011. The building is not only historically significant but also possesses impressive colonial architectural values.

\section{ARCHITECTURE STYLE}

One of the unique architectures brought by the British to Malaya is the Tudor architecture. The Tudor era emerged in England around the $15^{\text {th }}$ and $16^{\text {th }}$ centuries and in Malaysia, the style had existed for almost a century. This style of architecture can be seen in the hill resorts of Fraser's Hill and Cameron Highlands, Pahang. The buildings in Fraser's Hills and Cameron Highlands, are considered as Colonial heritage buildings and are known as the Tudor Revival (Bahauddin, Mohamed, Mat Som, Irwana, \& Othman, 2010). The Tudor or Tudor Revival style is an architecture design developed at the final period of medieval architecture during the Tudor period (1485-1603) and even beyond (Tudor revival architecture, n.d.). The style of Tudor Revival architecture is also found in the Carcosa. Carcosa is located in a hilly area similar to Cameron Highland and Fraser Hill. With the eclectic fusion of Neo-Gothic and Tudor Revival styles, the typical features are steeply pitched-roofs, complemented by a decorative halftimber front gable that is distinct of the Elizabethan era and an ornamental medieval parapet at the front of the building (Barber, 2007). 


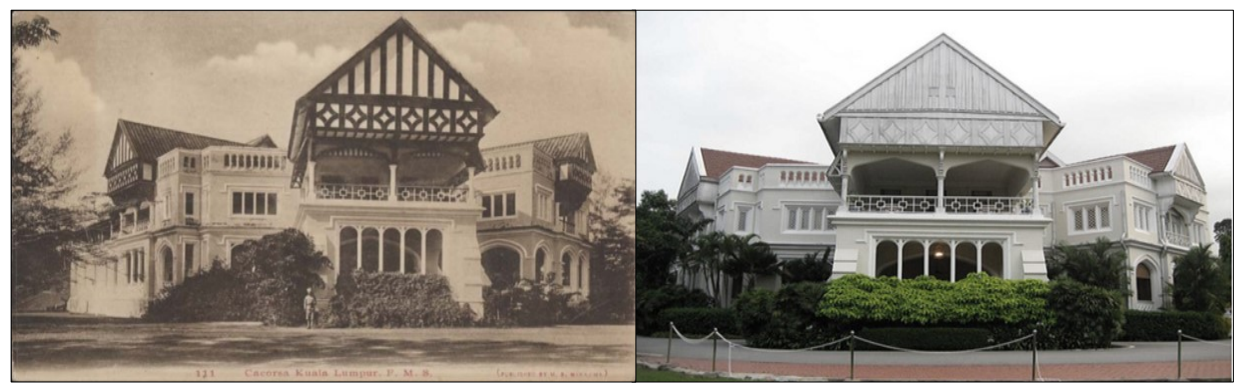

Figure 1: Carcosa in year 1900 (left) and the building in 2018 (right), still remain the original form and design, however the decorative timber at front gable has been painted and covered the Tudor features. Source: Cheah (2008); Harun (2018)

\section{HISTORIC BUILDING CONSERVATION}

Harun (2011a, 2011b) highlighted the importance of historic places to be preserved and the information of these historic places to be documented for the purposes of conservation of the historic buildings. Innovations can be seen through the architectural style and design, materials and texture, and also the buildings technique and construction. However, to determine the types of restoration work done to the buildings in the past is not easy, especially if the building has undergone several building extensions or physical alterations. Buildings listed in the National Heritage list need to be carefully and thoroughly evaluated, especially if the buildings are planned to be restored to their former glory. According to Jokilehto (2007), the conservation of cultural heritage is based on the methodology driven by the decision-making process, while Rocchi (2016) emphasised that the decision on the methodology used for restoration or rehabilitation work is the basic element before the restoration work started. Although several benefits of conserving architectural heritage have been identified and discussed by scholars, the interior conservation also needs to be emphasised, especially for the future use of these historic buildings. For that matter, the historical assessment of the interior with detailed interior and exterior assessment are needed for the conservator or building inspector before they are able to draw some conclusions on the conditions of these historic buildings and later outline the interior conservation scope. Under the National Trust for Historic Preservation (Grimmer, 2017), building owners who decide to restore their historic property, need to seek advice from experts on the methods and suitable procedure to restore the historic building (see Table 1). 
PLANNING MALAYSIA

Journal of the Malaysia Institute of Planners (2020)

Table 1: The Guidance for Restoration of Historic Interior

\begin{tabular}{ll}
\hline $\begin{array}{l}\text { Identify the factors that will } \\
\text { shape the decision }\end{array}$ & $\begin{array}{l}\text { Deciding whether to restore or rehabilitate and to } \\
\text { what extent, involves understanding its history; its } \\
\text { architecture; and the present condition of its } \\
\text { materials, finishes, and systems. }\end{array}$ \\
\hline Review the building's history & $\begin{array}{l}\text { Who lived in the building and when? Did important } \\
\text { events occur there? Did either (or both) scenarios } \\
\text { have historical significance? If so, should consider } \\
\text { restoring the building to that period to help interpret } \\
\text { its history. }\end{array}$ \\
\hline Know what "restore" means & $\begin{array}{l}\text { To restore a house means to return its interior and } \\
\text { exterior appearance to a particular date or period. }\end{array}$ \\
& $\begin{array}{l}\text { Strict restorations - ones that eliminate everything } \\
\text { not present during the period chosen - are rare for }\end{array}$ \\
homes, with most owners opting to maintain modern \\
systems (plumbing, anyone?) and sympathetically \\
designed changes, such as later additions, that add to \\
the house's history.
\end{tabular}


Siti Norlizaiha Harun, Norashikin Abdul Karim, Afzanizam Muhammad \& Shaari Mohd Sood

Assessment of the Historic Interior of Carcosa Heritage Building, Kuala Lumpur for Building Conservation

way, the house's history is visible and transparent. Also be careful not to design additions that make the house appear to date from an earlier or later period, or alter the house's details to the extent that suggest a different architectural period.

Restoring historic interior is also interpreted as restoring the historic character of interior building property, including detailing of interior materials, mouldings and stairways, room configuration and spatial relationships, as well as structural and mechanical systems (Morton \& Hume, 1983; Morton \& Hume, 1997). Moreover, restoring historic interior schemes for the purposes of preserving interior features which are considered as architectural elements, are essential to the characteristic of the designated landmark (Alliance Greater Philadelphia, 2007). Therefore, to achieve this objective, the authenticity and historic integrity criteria should be followed especially in terms of its location; setting; design; material; workmanship; feeling; and association (Jokilehto, 2006; Alho et al., 2010). In terms of the authenticity and historic integrity of Carcosa building, it is confirmed that the building has undergone several renovations works due to its functional change. However, the association and location of the renovations in the interior's space can still be identified.

\section{HISTORIC INTERIOR INVESTIGATION OF CARCOSA BUILDING}

The USA secretary of the interior's standards for the treatment of historic properties United States of America (Grimmer, 2017) has published a comprehensive guideline for preserving, rehabilitating, restoring, and reconstructing historic buildings. The document can be a useful reference and practice for historic interior conservation in Malaysia. Under the chapter of historic space, features, and furnishing, the restoration treatment focuses on investigation terminology and methodology. The interior floor plan, the arrangement and sequence of spaces, and built-in features and applied finishes are individually and collectively crucial in defining the historic character of the building. Interiors are typically composed of a series of primary and secondary spaces. Primary spaces, including entrance halls, lobbies, double parlours, living rooms, corridors, and assembly spaces, are defined not only by their function, but also by their location, features, finishes, size, and proportion. Meanwhile, secondary spaces in historic interiors are generally more functional than decorative, and depending on the building's use, may include kitchens, bathrooms, utility rooms, attics, basements, mailrooms, rear hallways, and most office spaces. Based on this reference, the historical interior assessment of the Carcosa mansion aims to justify the degree of the renovation of the interior floor plan and whether they comply with the preservation standard or not. Based on figure 3 and 4, although the secondary spaces were prominent in the building's function historically, they are generally less significant than primary spaces. 
Thus, secondary spaces are usually the most appropriate places to be altered, which may be necessary for a historic building, such as those that are required to meet specific codes or to install mechanical equipment. Based on this guidance, the changes in the interior layout of the Carcosa mansion can be acceptable since the changes still preserve the exterior appearance of the mansion.

\section{CHANGES OF SPACE AND INTERIOR LAYOUT}

The Carcosa mansion started its function as a hotel in 1989 and ended operation in 2016. Marketed as a luxurious heritage boutique hotel, much of the mansion's colonial architecture and interior were preserved, carefully adapted and complemented with colonial themed-hotel service. The original space and layout were designed as a mansion and British residence office. The 2-storey mansion has more than eight bedrooms, including the master bedroom and guest rooms, a spacious living room surrounded by a corridor terrace or veranda at the ground and first floor, and eleven bathrooms.

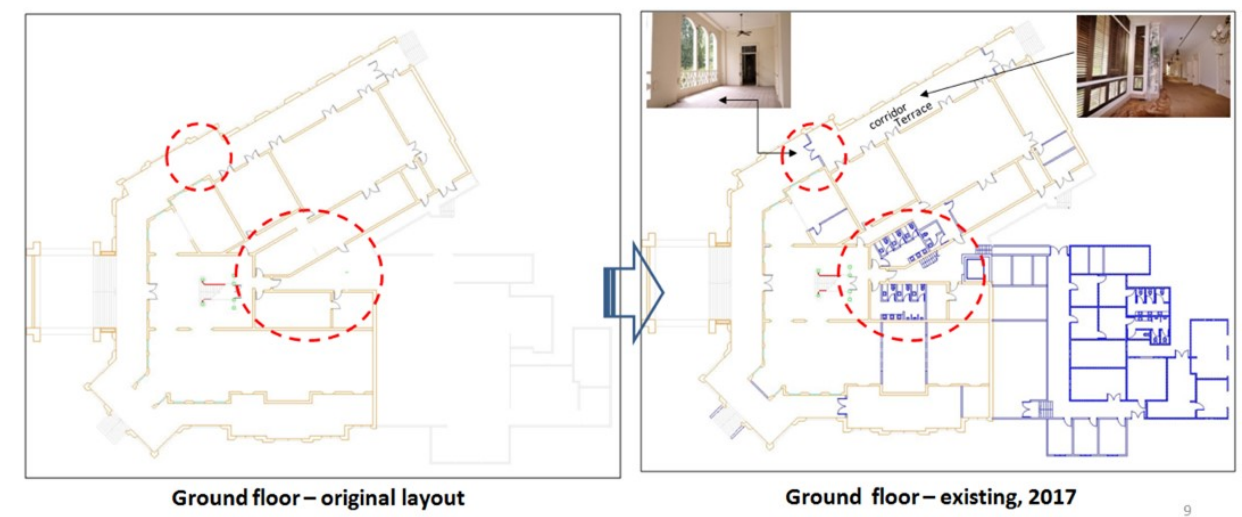

Figure 3: Corridor terrace (A) has been closed for part of expansion of hotel suite room. New toilets and refreshment room (B) has been added behind the main staircase. Source: Harun (2018)

In 1989, during Queen Elizabeth's II visit, she occupied Swettenham's spacious suite rooms, which had been redecorated in the Victorian style (Warren $\&$ Gocher, 2007). In the year 1997, the mansion was renovated again, acquiring a spa, satellite TV, and upgraded kitchen while preserving the original appearance of the building (Warren \& Gocher, 2007). Besides the interior preservation, to meet the hotel requirement, especially the number of rooms and facilities, part of the corridor and terrace at the ground and the first floor was closed for new rooms and toilets (Figure 3 and 4). 
Siti Norlizaiha Harun, Norashikin Abdul Karim, Afzanizam Muhammad \& Shaari Mohd Sood

Assessment of the Historic Interior of Carcosa Heritage Building, Kuala Lumpur for Building Conservation

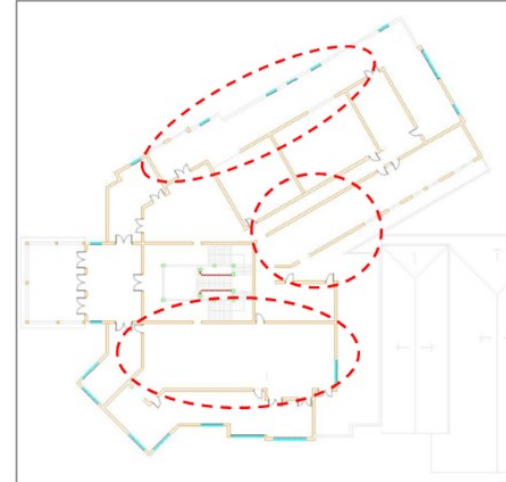

First floor-original

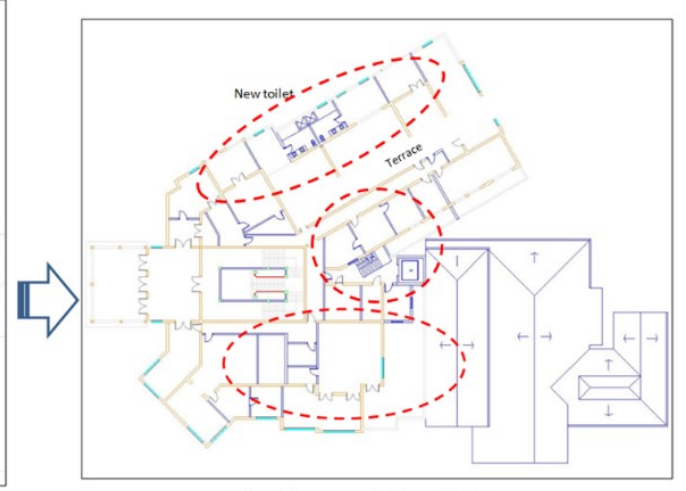

First floor-existing, 2017

Figure 4: Corridor and terrace at first floor (A and B) closed for new rooms and toilets. The main hall $(\mathrm{C})$ been renovated as hotel suite room. Source: Harun (2018)

\section{INTERIOR FEATURES AND FINISHES}

The historical evidence of Carcosa's interior features was challenging to trace. Most of the historical documents such as old photos captured the exterior part of the building architecture. However, through the investigation of the function of the original space and rooms, the interior features of this building are luxuriously tailored to the status of the residence for the British Resident-General. The ground floor lobby area was built with a stunning wooden staircase. Since the building was influenced by the Tudor style, most of the interior decoration elements were from wood. The ceiling beams, window and door casings, wainscots, and staircases tended to be dark and heavy, made of hardwood finished with wax. Based on the site inspection, all wooden elements, especially in the lobby area, were painted in cream and thick paint had covered the carvings, the surface of the staircase, newel post and cap. This is due to the new user wanting the interior scheme of Carcosa to be appropriate with the new function of Carcosa. In this case, it is preferable that the original scheme be retained with original interior features, material and finishes.
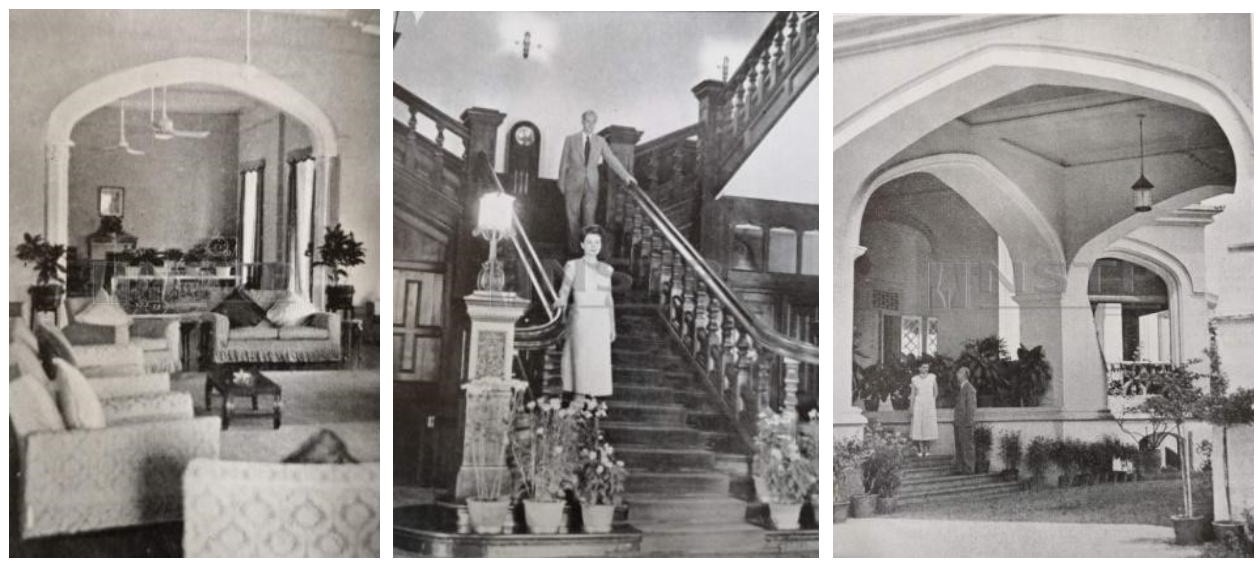
Figure 5: Carcosa during British Resident. The historical photos captured this historic moment of the mansion; (a) The spacious rooms were lavishly furnished, (b) The grand staircase, and (c) Carcosa's spacious porch.

Source: Seng (2018)
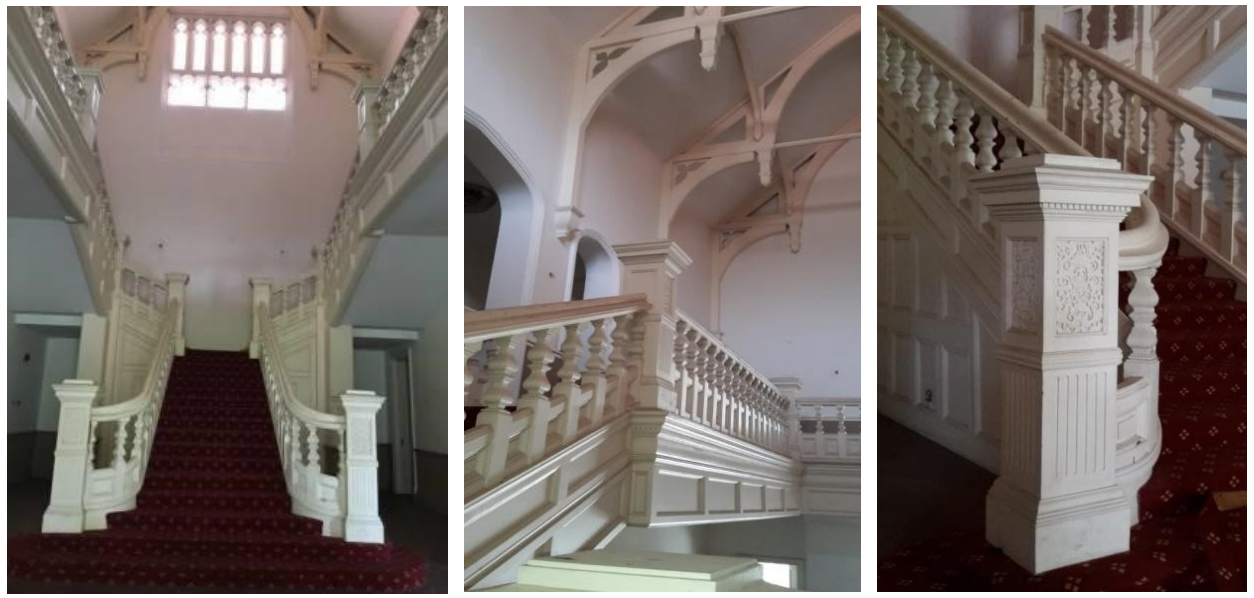

Figure 6: The existing timber staircase. All components, including the railing, balustrade, and decorative elements had been painted in cream thick paint.

Sources: Author (2018)

\section{FINDING AND CONCLUSION}

The investigation of Carcosa's historic building has identified significant challenges in building conservation practice in Malaysia. The scope of the investigation was focused on searching the authenticity of the interior features of the historic building. The results and findings from various investigations have brought hope for the future of this historic colonial building. A study proposes the existing structure remains but removes the renovated wall of the corridor terrace and restores the original interior schemes to all rooms on the first floor. All spaces at the ground floor and terrace proposed to remain but with minor restoration of the timber material. All timber surfaces that have been painted, especially the staircase, cantilever, and wainscot panel need to be restored to its original glory. Referring to the interior historic building guideline (Rocchi, 2016; Grimmer, 2017), all interior schemes have been suggested to follow the original scheme or at least to be assimilated with the features of British colonial style through the furniture and decorations. The future use of this historic building should consider the quality, design, materials, and craftsmanship of the original building, as well as the changes that have occurred over time. Renovation done to the building that is compatible with its design can be kept and restored. By this finding and guideline, the true history of the building will be visible and the information of the architectural period, interior scheme and conservation can be 
Siti Norlizaiha Harun, Norashikin Abdul Karim, Afzanizam Muhammad \& Shaari Mohd Sood

Assessment of the Historic Interior of Carcosa Heritage Building, Kuala Lumpur for Building Conservation

used by the future generation. In conclusion, this research can be a basic guidance in preserving historic interior for heritage building, especially when applying planning permission for conservation and adaptive re -use.

\section{ACKNOWLEDGEMENTS}

The authors wish to express a gratitude to the National Heritage Department for giving permission to access Carcosa Seri Negara as a case study for this research.

\section{REFERENCES}

Alliance Greater Philadelphia. (2007). Protecting Historic Interiors: A Survey of Preservation Practices and Their Implications for Philadelphia. Retrieved from http://www.preservationalliance.com/publications/InteriorsFINAL.pdf

Alho, C., Morais, A., Mendes, J., \& Galvao, A. (2010). Authenticity Criteria in Conservation of Historic Buildings. Cib 2010 World Conference, Building a Better World, 188-198.

Bahauddin, A., Mohamed, B., Mat Som, A. P., Irwana, S, \& Othman, A. G. (2010). The British Colonial architectural heritage of Fraser's Hill and Cameron Highlands, Malaysia. 3rdAsia-Euro Tourism, Hospitality and Gastronomy Conference Transformation and Modernisation in Tourism, Hospitality and Gastronomy. Subang Jaya, Kuala Lumpur

Barber, A. (2007). Malaysian moments: A pictorial retrospective (p. 60). Kuala Lumpur: AB \& A Publisher.

Brida, J. G., Disegna, M., \& Scuderi, R. (2012). The visitors' perception of authenticity at the museums: Archaeology versus modern art. Current Issues in Tourism. 10.1080/13683500.2012.742042.

Cheah, J. S. (2008). Malaya: 500 early postcards. Singapore: Editions Didier Millet Pte Ltd.

Grimmer, A. E. (2017). The Secretary of the Interior's Standards for the treatment of historic properties with guideline for preserving, rehabilitating, restoring and reconstructing historic building. Washington, DC: U.S. Department of the Interior, National Parks Services, USA.

Harun, S. N. (2011a). Heritage building conservation in Malaysia. Retrieved from http://kota-city.blogspot.com/2011/04/heritage-building-conservation-in.html

Harun, S. N. (2011b). Heritage building conservation practice in Malaysia: Experience and challenges. Procedia Engineering, 20, 41-53. https://doi.org/10.1016/j.proeng.2011.11.137

Jokilehto, J. (2007). An international perspective to conservation education. Built Environment, 33(3), 275-286.

Jokilehto, J. (2011). ICCROM_The Conservation of Cultural Heritage_A History of the Organization's first 50 years 1959-2009.

McDonald, T. C. (1994). Understanding old buildings (The process of architectural investigation) - Preservation brief 35. Heritage Preservation Services, National Park Service. Retrieved from http:///www2.cr.nps.gov/tps/briefs/brief35.htm

Morton, B., \& Hume, G. (1983). Standards for Rehabilitation and Guidelines for Rehabilitating Historic Buildings. 
Morton, B., Hume, G., Weeks, K. D., \& Jandl, H. W. (1997). The Secretary of the Interior's Standards for Rehabilitation \& Illustrated Guidelines for Rehabilitating Historic Buildings. U.S. Department of the Interior National Park Service. Washington, D.C.

Nara Document on Authenticity. (1994). Nara Conference on Authenticity in Relation to the World Heritage Convention. Nara, Japan.

National Heritage Department Malaysia (2017). Historic Building Conservation Guideline.

Pearson, M., \& Marshall, D. (2011). Study of condition and integrity of historic places Report prepared for the Australian Government Department of Sustainability, Environment, Water, Population and Communities on behalf of the State of the Environment 2011 Committee. Canberra: DSEWPaC.

Rocchi, J. (2016). 10 tips: Restoring vs. rehabilitation your historic house. Retrieved from https://savingplaces.org/stories/10-on-tuesday-restore-vs-rehabilitatewhich-is-right-for-your-historic-house\#.XG4ps-GeXD0

Seng, A. T. L. (2018). Rising from the ashes - the Carcosa story. New Straits Times. Retrieved from https://www.nst.com.my/lifestyle/sundayvibes/2018/11/435673/rising-ashes-\%E2\%80\%93-carcosa-story

Tudor revival architecture. In Wikipedia (2019). Retrieved February 20, 2019 from https://en.wikipedia.org/wiki/Tudor_Revival_architecture

Warren, W., \& Gocher, J. (2007). Asia's legendary hotels: The romance of travel (p. 164). Singapore: Periplus Editions

Weaver, M. E. (1997). Conserving buildings: A manual of techniques and material. New York: Chichester Wiley.

Received: January 2020. Accepted: $1^{\text {st }}$ April 2020 